\title{
Front Matter: Volume 10117
}

, "Front Matter: Volume 10117," Proc. SPIE 10117, Emerging Digital Micromirror Device Based Systems and Applications IX, 1011701 (5 April 2017); doi: $10.1117 / 12.2276169$

SPIE. Event: SPIE OPTO, 2017, San Francisco, California, United States 


\title{
PROCEEDINGS OF SPIE
}

\section{Emerging Digital Micromirror Device Based Systems and Applications IX}

\author{
Michael R. Douglass \\ Benjamin L. Lee \\ Editors
}

30-31 January 2017

San Francisco, California, United States

Sponsored by

SPIE

Cosponsored by

DLP Texas Instruments (United States)

Published by

SPIE 
The papers in this volume were part of the technical conference cited on the cover and title page. Papers were selected and subject to review by the editors and conference program committee. Some conference presentations may not be available for publication. Additional papers and presentation recordings may be available online in the SPIE Digital Library at SPIEDigitallibrary.org.

The papers reflect the work and thoughts of the authors and are published herein as submitted. The publisher is not responsible for the validity of the information or for any outcomes resulting from reliance thereon.

Please use the following format to cite material from these proceedings:

Author(s), "Title of Paper," in Emerging Digital Micromirror Device Based Systems and Applications IX, edited by Michael R. Douglass, Benjamin L. Lee, Proceedings of SPIE Vol. 10117 (SPIE, Bellingham, WA, 2017) Seven-digit Article CID Number.

ISSN: 0277-786X

ISSN: 1996-756X (electronic)

ISBN: 9781510606753

ISBN: 9781510606760 (electronic)

Published by

SPIE

P.O. Box 10, Bellingham, Washington 98227-0010 USA

Telephone +1 3606763290 (Pacific Time) · Fax +1 3606471445

SPIE.org

Copyright @ 2017, Society of Photo-Optical Instrumentation Engineers.

Copying of material in this book for internal or personal use, or for the internal or personal use of specific clients, beyond the fair use provisions granted by the U.S. Copyright Law is authorized by SPIE subject to payment of copying fees. The Transactional Reporting Service base fee for this volume is $\$ 18.00$ per article (or portion thereof), which should be paid directly to the Copyright Clearance Center (CCC), 222 Rosewood Drive, Danvers, MA 01923. Payment may also be made electronically through CCC Online at copyright.com. Other copying for republication, resale, advertising or promotion, or any form of systematic or multiple reproduction of any material in this book is prohibited except with permission in writing from the publisher. The CCC fee code is 0277-786X/17/\$18.00.

Printed in the United States of America.

Publication of record for individual papers is online in the SPIE Digital Library.

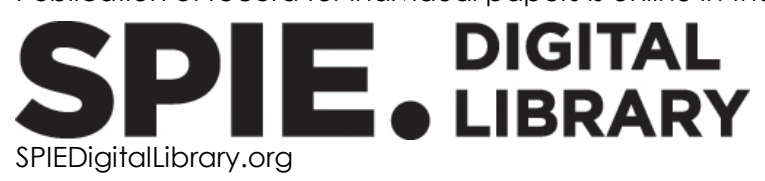

Paper Numbering: Proceedings of SPIE follow an e-First publication model. A unique citation identifier (CID) number is assigned to each article at the time of publication. Utilization of CIDs allows articles to be fully citable as soon as they are published online, and connects the same identifier to all online and print versions of the publication. SPIE uses a seven-digit CID article numbering system structured as follows:

- The five digits correspond to the SPIE volume number.

- The last two digits indicate publication order within the volume using a Base 36 numbering system employing both numerals and letters. These two-number sets start with $00,01,02,03,04$, 05, 06, 07, 08, 09, OA, OB ... 0Z, followed by 10-1Z, 20-2Z, etc. The CID Number appears on each page of the manuscript. 


\title{
Contents
}

\author{
$\checkmark$ Authors \\ vii Conference Committee
}

SESSION 1 BEAM SHAPING

1011703 Micro mirrors based coupling of light to multi-core fiber realizing in-fiber photonic neural network processor [10117-2]

SESSION 2 ADVANCED FABRICATION WITH DMD AND SLM DEVICES: JOINT SESSION WITH CONFERENCES 10115 AND 10117

1011705 Reaction of photochemical resists used in screen printing under the influence of digitally modulated ultra violet light [10117-4]

SESSION 3 3D METROLOGY: JOINT SESSION WITH CONFERENCES 10115 AND 10117

1011707 High-speed 3D imaging using digital binary defocusing method vs sinusoidal method (Invited Paper) [10117-7]

1011708 Advanced optical 3D scanners using DMD technology (Invited Paper) [10117-8]

1011709 Calibration for 3D imaging with a single-pixel camera [10117-9]

10117 OA Fiber-optic fringe projection with crosstalk reduction by adaptive pattern masking [10117-10]

SESSION 4 BIOMEDICAL IMAGING USING A DMD OR OTHER LIGHT STRUCTURING DEVICES: JOINT SESSION WITH CONFERENCES 10068 AND 10117

10117 OB Light-induced quantitative microprinting of biomolecules [10117-11]

10117 OE Controlled power delivery for super-resolution imaging of biological samples using digital micromirror device [10117-25]

10117 OF Improvement of axial excitation confinement in temporal focusing-based multiphoton microscopy via spatially modulated illumination [10117-15] 
$101170 G$ Compressive sensing for single-shot two-dimensional coherent spectroscopy (Invited Paper) [10117-16]

$10117 \mathrm{OH} \quad$ Side information in coded aperture compressive spectral imaging (Invited Paper) [10117-17]

10117 OJ Conceptual design for an AIUC multi-purpose spectrograph camera using DMD technology [10117-19]

10117 OK A method of incident angle estimation for high resolution spectral recovery in filter-arraybased spectrometers [10117-20]

\section{SESSION 6 COMPUTATIONAL IMAGING AND ADVANCED APPLICATIONS}

$10117 \mathrm{OL}$ The CAOS camera platform: ushering in a paradigm change in extreme dynamic range imager design (Invited Paper) [10117-21]

10117 OM Full-color stereoscopic single-pixel camera based on DMD technology [10117-22]

10117 ON A novel emissive projection display (EPD) on transparent phosphor screen [10117-23] 


\section{Authors}

Numbers in the index correspond to the last two digits of the seven-digit citation identifier (CID) article numbering system used in Proceedings of SPIE. The first five digits reflect the volume number. Base 36 numbering is employed for the last two digits and indicates the order of articles within the volume. Numbers start with $00,01,02,03,04,05,06,07,08,09,0 A, 0 B . .0 Z$, followed by 10-1Z, 20-2Z, etc.

Arce, Gonzalo R., $\mathrm{OH}$

Arguello, Henry, $\mathrm{OH}$

Azioune, Ammar, $\mathrm{OB}$

Barrientos, F., OJ

Baver, F., OJ

Boate, Alan R., 09

Boukerche, Azzedine, 09

Bugnicourt, Ghislain, OB

Cadby, Ashley, OE

Chahid, Makhlad, OB

Chang, Chia-Yuan, OF

Chen, Shean-Jen, OF

Cheng, Botao, ON

Cho, Jeonghoon, OK

Clemente, Pere, $0 \mathrm{M}$

Cohen, Eyal, 03

Drass, H., OJ

Galvis, Laura, $\mathrm{OH}$

Gmuender, T., 05

Godding, R., 08

Gribben, Jeremy, 09

Harel, E., OG

Hermstein, M., 08

Hyun, Jae-Sang, 07

Jordan, A., OJ

Ju, Gun Wu, OK

Kästner, Markus, OA

Kim, Cheolsun, OK

Kim, Seongmin, OK

Lancis, Jesús, OM

Lau, Daniel, $\mathrm{OH}$

Lecomte, Yohan, $\mathrm{OB}$

Lee, Heung-No, OK

Lee, Woong-Bi, OK

Lee, Yong Tak, OK

Li, Beiwen, 07

Lim, Dongsung, OK

London, Michael, 03

Malka, Dror, 03

Matthias, Steffen, OA

Muenstermann, P., 08

Oh, Jinkyung, OK

Pla, Filiberto, OM

Reithmeier, Eduard, OA

Riza, Nabeel A., OL

Rukdee, S., OJ

Salvador-Balaguer, Eva, OM

Shahmoon, Asaf, 03

Shemer, Amir, 03
Spencer, A., OG

Spokoyny, B., OG

Strale, Pierre-Olivier, $O B$

Studer, Vincent, OB

Sun, Leonard, ON

Sun, Ted X., ON

Tajahuerce, Enrique, OM

Valiya Peedikakkal, Liyana, OE

Vanzi, L., OJ

Yu, Ge, ON

Zalevsky, Zeev, 03

Zhang, Song, 07 
Proc. of SPIE Vol. 10117 1011701-6 Downloaded From: https://www.spiedigitallibrary.org/conference-proceedings-of-spie on 26 Apr 2023
Terms of Use: https://www.spiedigitallibrary.org/terms-of-use 


\section{Conference Committee}

Symposium Chairs

Jean-Emmanuel Broquin, IMEP-LAHC (France)

Shibin Jiang, AdValue Photonics, Inc. (United States)

Symposium Co-chairs

Connie J. Chang-Hasnain, University of California, Berkeley

(United States)

Graham T. Reed, Optoelectronics Research Centre, University of

Southampton (United Kingdom)

Program Track Chairs

Holger Becker, microfluidic ChipShop GmbH (Germany)

Winston V. Schoenfeld, CREOL, The College of Optics and Photonics, University of Central Florida (United States)

Conference Chairs

Michael R. Douglass, Texas Instruments Inc. (United States)

Benjamin L. Lee, Texas Instruments Inc. (United States)

Conference Program Committee

Sara L. Best, University of Wisconsin School of Medicine and Public Health (United States)

Roland Höfling, ViALUX GmbH (Germany)

Alfred Jacobsen, Visitech Engineering GmbH (Germany)

Yuval Kapellner Rabinovitz, EKB Technologies Ltd. (Israel)

Badia Koudsi, Optecks, LLC (United States)

Jinyang Liang, Washington University in St. Louis (United States)

Sanjeev Kumar M., Texas Instruments Pvt. Ltd. (India)

Hakki H. Refai, Optecks, LLC (United States)

David Smith, Wintech Digital Systems Technology Corporation

(United States)

Brandon A. Sosa, Greenlight Optics, LLC (United States)

Karel J. Zuzak, University of Texas Southwestern Medical Center (United States) and The Laboratory of Biomedical Imaging and

Engineering, LBI-51, LLC (United States) 


\section{Session Chairs}

1 Beam Shaping

Yuval Kapellner Rabinovitz, EKB Technologies Ltd. (Israel)

Jinyang Liang, Washington University in St. Louis (United States)

2 Advanced Fabrication with DMD and SLM Devices: Joint Session with Conferences 10115 and 10117

Michael R. Douglass, Texas Instruments Inc. (United States)

Georg von Freymann, Technische Universität Kaiserslautern (Germany)

3 3D Metrology: Joint Session with Conferences 10115 and 10117

Sanjeev Kumar M., Texas Instruments Pvt. Ltd. (India)

Alfred Jacobsen, Visitech Engineering GmbH (Germany)

4 Biomedical Imaging using a DMD or other Light Structuring Devices:

Joint Session with Conferences 10068 and 10117

Mike Douglass, Texas Instruments Inc. (United States)

$5 \quad$ Spectroscopy and Hyperspectral Imaging

Karel J. Zuzak, University of Texas Southwestern Medical Center

(United States) and The Laboratory of Biomedical Imaging and

Engineering, LBI-51, LLC (United States)

Benjamin L. Lee, Texas Instruments Inc. (United States)

6 Computational Imaging and Advanced Applications

Michael R. Douglass, Texas Instruments Inc. (United States) 